\title{
PEMASARAN PRODUK UKM PADA SOSIAL MEDIA INSTAGRAM SEBAGAI SARANA ONLINE MARKETING KERJASAMA DENGAN KELURAHAN PARUNG SERAB
}

\author{
Sejati Waluyo*, Wahyu Pramusinto, Ferdiansyah, Ika Susanti \\ Universitas Budi Luhur, Indonesia \\ *sejati.waluyo@budiluhur.ac.id
}

\begin{abstract}
The development of online marketing affects how a product is marketed. The process of selling and buying transactions is not only done conventionally but also online. Online product marketing is also widely used by large companies to increase their sales profit. The advantage of using online marketing is that it does not recognize the limitations of place and time and can work for 24 hours. There are lots of online marketing channels that can be used as online marketing, one of which is Instagram social media. There have been many successful SMEs who run their business in the internet world. In this community service, they work together with UKM Parung Serab Village to be able to improve and introduce existing UKM products to the public so that they can increase the sales turnover of UKM Parung Serab Village.
\end{abstract}

Keywords: social media Instagram, online marketing, internet.

\begin{abstract}
Abstrak
Semakin berkembanganya online marketing, mempengaruhi bagaimana suatu produk dipasarkan. Proses transaksi penjualan maupun pembelian tidak hanya di lakukan secara konvensional akan tetapi juga secara online. Pemasaran produk secara online juga banyak dimanfaatkan perusahan besar untuk meningkatkan profit penjualan mereka. Kelebihan dengan memanfaatkan online marketing adalah tidak mengenal Batasan tempat dan waktu dan dapat bekerja selama 24 jam. Ada banyak sekali chanel online marketing yang dapat digunakan sebagai online marketing, salah satunya adalah social media Instagram. Sudah banyak UKM sukses yang menjalani bisnisnya didunia internet. Pada pengabdian kepada masyarakat ini bekerja sama dengan UKM kelurahan parung serab untuk dapat meningkatkan dan mengenalkan produk UKM yang ada pada publik sehingga dapat meningkatkan omset penjualan UKM kelurahan parung serab.
\end{abstract}

Kata Kunci: social media intragram, online marketing, internet.

\begin{tabular}{l|l|l} 
Submitted: $2021-08-08$ & Revised: $2021-10-11$ & Accepted: 2021-10-26
\end{tabular}

\section{Pendahuluan}

Penggunaan internet saat ini, semakin lama semakin meningkat. Internet tidak hanya dijadikan media untuk mencari informasi saja melainkan sudah banyak digunakan untuk keperluan bisnis. Diantaranya adalah internet digunakan untuk shelling, pemasaran, penjualan produk dan jasa, pengenalan dan penguatan brand maupun produk kepada masyarakat. Internet juga sangat berperan penting dalam dunia pendidikan saat ini. Banyak sekali manfaat internet yang kita dapat, dalam meningkatkan maupun memajukan bisnis yang kita jalani.

Peranan Internet dalam dunia bisnis yang sangat signifikan adalah berubahnya konsep pemasaran yang dilakukan oleh perusahaan. Perusahaan mulai memanfaatkan Internet sebagai ajang promosi ke seluruh dunia dengan membuat sebuah situs resmi perusahaan. Situs perusahaan umumnya menampilkan company profile, produk yang dijual dan berita menyangkut aktivitas perusahaan. Perusahaan juga menyediakan fasilitas email bagi orang yang hendak menghubungi perusahaan. Tidak hanya perusahaan besar bahkan perusahaan yang lebih kecilpun memiliki situs karena membuat sebuah situs tidaklah sulit dan biayanya relatif terjangkau. Yang membedakan adalah tampilan situs terebut dimana situs perusahaan besar biasanya dikelola secara khusus sehingga data dan tampilannya sering diperbarui. Internet juga dijadikan sebagai media untuk menggaet calon konsumen atau pelanggan (Bidang Politik \& Dan Sosial Budaya James Situmorang, n.d.).

Kelurahan parung serab terletak di kecamatan ciledug, Kota tangerang. Di kelurahan parung serab ini, sudah terdapat UKM yang bergerak di bidang berbagai bidang. Meskipun demikian masih 
perlu dilakukan promosi produk untuk meningkatkan pendapatan mereka terutamanya dalam hal pemasaran produk secara online. Adapun permasalahan yang di hadapi oleh mitra adalah belum adanya pelatihan bagaimana cara meningkatkan daya saing bisnis yang ada dimasyarakat kelurahan parung serab. Serta bagaimana memanfaatkan sosial media instagram sebagai sarana online marketing bagi masyarakat untuk menawarkan produk mereka.

Sekretaris Kementerian Koperasi dan UKM Agus Muharram menekankan pentingnya Usaha Mikro Kecil Menengah (UMKM) memanfaatkan keberadaan media sosial (medsos) untuk meningkatkan kinerja penjualan produknya. Menurut Agus, dengan memanfaatkan media sosial maka hambatan jarak, ruang dan waktu, serta harga barang, bisa tereliminir. Selain itu, UKM juga tidak lagi membutuhkan ruang yang besar untuk memajang produknya. "Jarak juga tidak menjadi hambatan untuk mengirim barang, karena sudah banyak perusahaan jasa kurir untuk mengantar barang dengan harga yang murah dan cepat sampai ke konsumen. Jangkauan pemasaran pun bisa mendunia. Tenaga kerja juga bisa dimanfaatkan dengan efektif dan efisien," kata Agus pada acara workshop bertema Pentingnya Sosial Media Untuk UMKM Dalam Meningkatkan Penjualan, di Jakarta, Senin (31/7/2017). Oleh karena itu, Agus berharap para pelaku UMKM di Indonesia sudah mulai melangkah mempromosikan dan menjual produknya melalui media sosial agar tidak tergilas zaman. "Media sosial hanyalah sebagai alat. Kita harus tetap memiliki pengetahuan dasar yang kuat dalam berbisnis," kata Agus (Pramdia Arhando Julianto, n.d.).

Penggunaan media sosial digunakan oleh masyarakat dalam melakukan banyak aktivitas mulai dari entertainment, melaku-kan bisnis, mencari info atau aktivitas lain-nya. Pengguna internet aktif di Indonesia per Januari 2016 mencapai 88.1 juta orang dan 79 juta di antaranya merupakan pengguna media sosial yang aktif (Balea, 2016). Instagram sebagai salah satu media sosial populer di Indonesia berada di peringkat kedelapan dengan pengguna mencapai $10 \%$. Berdasarkan sumber e-marketer.com (2017), penggunaan instagram di Indonesia bagi pengguna dengan usia 16-35 tahun, melakukan posting foto-foto saat travelling mencapai $48.4 \%$ (peringkat ketiga). Di Indonesia, jumlah pengguna instagram aktif mencapai 22 juta orang. Adapun dengan persebaran demografi pengguna instagram 18-29 tahun memiliki penggunaan terbesar yaitu $83 \%$. Namun $18 \%$ dari mereka yang berumur 30-49 tahun dan 6\% dari umur 50-64 tahun juga menggunakan instagram. Berdasarkan data tersebut, maka instagram merupakan salah satu media yang potensial untuk digunakan sebagai media promosi (Indika \& Jovita, 2017).

Banyaknya manfaat penggunaan media sosial dalam mengembangkan UKM merupakan salah satu faktor pendorong yang kuat bagi UKM untuk terus memanfaatkan media sosial dalam rangka mengembangkan usahanya, meningkatkan penjualan produk, melakukan komunikasi dengan konsumen, serta mengembangkan jaringan pasar yang lebih luas lagi. hal ini senada dengan penelitian sebelumnya, yang menunjukkan bahwa persepsi terhadap manfaat penggunaan teknologi informasi merupakan salah satu faktor pendorong bagi UKM untuk menggunakan media teknologi informasi. Sosial media merupakan salah satu media yang mempermudah komunikasi interaktif antara pengusaha dengan siapapun, termasuk konsumen, dan berbagai pihak yang berkepentingan, kapanpun dan berada dimanapun. Sosial media sangat membantu sebagai penghubung informasi dan komunikasi dari produsen ke konsumen di manapun mereka berada dan berapapun jaraknya (Moch et al., 2016).

\section{Metode}

Dalam pelaksanaan pengabdian kepada masyarakat perlu adanya metode pelaksanaan pengabdian kepada masyarakat sehingga kegiatan yang dilakukan dapat berjalan dengan baik. Adapun tahapan-tahapan yang dilakukan dalam pelaksanaan pengabdian kepada masyarakat adalah sebagai berikut: 
Analisa kondisi Mitra pengabdian kepada masyarakat, hal ini dilakukan guna mengetahui permasalahan yang dihadapi oleh mitra sehingga pelaksanaan pengadian kepada masyarakat menjadi tepat guna dan mampu menyelesaikan permasalahan ataupun kesulitan yang dihadapi oleh mitra.

Persiapan konsep dan administrasi kerjasama, dalam tahapan ini team pelaksana pengabdian kepada masyarakat berkomunikasi dengan pelaku UKM sehingga memiliki gambaran tentang UKM yang ada. Selain itu team pelaksana pengabdian kepada masyarakat juga melakukan kerja sama dengan kelurahan parung serab agar pelaksanan pengabdian kepada masyarakat ini diketahui oleh pihak kelurahan parung serab. Disini team pelaksana memaparkan kegiatan apa yang akan dilakukan sehingga mendapatkan persetujuan dari kelurahan parung serap.

Pembuatan bahan ajar, dalam tahap ini team pelaksana menyusun materi yang akan disampaikan pada saat pelaksanaan pengabdian kepada masyarakat dilakukan berdasarkan permasalahan yang telah didapat sebelumnya. Sehingga pada saat pelaksanaan pengabdian kepada masyarakat materi yang disampaikan sudah disesuaikan dengan kebutuhan yang ada.

Pelaksanaan pelatihan penggunaan sosial media instagram sebagai sarana online marketing, dalam tahap ini team palaksana menentukan tempat dan waktu pelaksanaan pengabdian kepada masyarakat sehingga kegiatan dapat dilaksanakan dengan baik. Karena dalam pelatihan ini juga dibutuhkan komputer dan akses internet yang mendukung jadi tempat pelaksanan pengabdian kepada masyarakat harus dapat memenuhi kebutuhan tersebut. Dalam pelatihan ini, selain penyampaian materi yang sudah disiapkan sebelumnya juga dilakukan sesi tanya jawab baik mengenai materi yang telah disampaikan maupun sharing pengalaman dunia usaha antar pesarta dengan narasumber, sehinga dapat diketahui tingkat pemahaman peserta terhadap pelaksanaan pelatihan penggunaan media sosial instagram sebagai sarana online marketing.

\section{Hasil dan Pembahasan}

Dalam pelaksanan program pengabdian kepada masyarakat ini, berupa pelatihan penggunaan Sosial Media Instagram sebagai Sarana Pemasaran produk UKM dengan konsep Online Marketing Berkerjasa sama dengan Kelurahan Parung Serab dan Dosen Kampus Universitas Budi Luhur.

Kondisi mitra sebelumnya pelatihan memasarkan produk melalui Media Instagram, pada umumnya peserta dapat mengoperasikan smartphone untuk akses internet guna mendapatkan informasi atau berita yang ada. Artinya mitra pengabdian kepada masyarakat ini tidak sepenuhnya awam terhadap perkembangan teknologi informasi terutama penggunaan smartphone untuk kebutuhan sehari-hari. Dan diantara peserta yang ada, juga sudah ada beberapa peserta yang mengetahui bagaimana menggunakan instagram untuk bisnis namun masih perlu adanya optimasi dalam pemanfaatan media instagram sebagai bisnis, serta sebagian juga belum pernah memanfaatkan instagram sebagai media bisnis. Serta para peserta pelatihan pengabdian kepada masyarakat belum mengetahui bagaimana menggunakan instagram ads untuk membantu mempromosikan produk yang mereka jual.

Dalam pengabdian kepada masyarakat ini juga membahas berbagai hal berkaitan dengan Konsep bagaimana penggunaan Instagram Untuk Bisnis serta pembuatan Accout Instagram bagi yang belum memilikinya. Dalam pelatihan juga dibahas pengertian dasar dan istilah yang digunakan dalam Instagaram. Semisal bagaimana memberikan caption dan deskripsi foto produk yang akan di upload, Bagaimana membuat Hastag berkatian dengan produk mereka, paid promote berupa jasa promosi oleh akun IG yang memiliki banyak follower. Serta Endorse yaitu jasa promosi produk oleh selegram maupun artis.

Bagi peserta yang belum memiliki akun instagram bisnis, diajarkan bagaimana membuat akun instagram bisnis. Akun bisnis yang dibuat tentu harus memperhatikan beberapa hal agar akun bisnis yang kita buat sering ditampilkan di instagram sehingga produk yang kita jual atau pasarkan 
berpotensi besar mendapatkan transaksi dari pembeli. Akun bisnis yang dibuat ini harus memperhatikan beberapa hal diantaranya adalah akun bisnis harus dibuat berdasarkan kata kunci produk kita, akun bisnis juga dapat dibuat berdasarkan hashtag yang paling banyak digunakan yang berkaitan dengan produk UKM yang dipasarkan, serta peserta pelatihan juga diajarkan untuk lebih kreatif dalam membuat akun bisnis tentang apa yang orang pikirkan sekira akan mencari sesuatu berkaitan dengan produk yang dipasarkan. Ini juga dapat dijadikan dasar dalam membuat akun bisnis Instagram kita.

Berikut ini adalah dokumentasi pelaksanaan kegiatan pengabdian kepada masyarakat, pengambilan gambar dokumentasi dilakukan sebelum masa pandemi dan pembatasan sosial bersekala besar dilakukan.

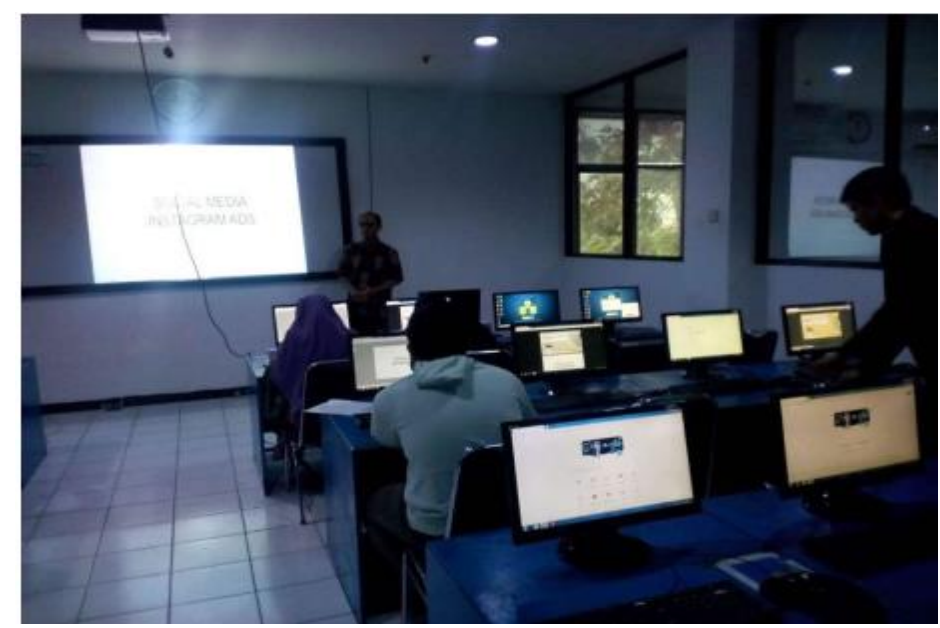

Gambar 1. Penggunaan sarana dan prasarana PKM

Dikarenakan ditempat mitra pengabdian kepada masyarakat tidak tersedia sarana berupa komputer dan projector yang digunakan untuk presentasi dan pelaksanaan pengabdian kepada masyarakat. Maka Tim Pelaksana pengabdian kepada masyarakat melakukan kerja sama dengan Lab ICT Universitas budi luhur, untuk melakukan pengabdian kepada masyarakat. Adapun fasilitas yang tersedia adalah komputer dengan kapasitas lebih kurang 35 orang. serta projector yang digunakan sebagai media presentasi dalam menyampaikan materi kepada peserta pelatihan. Lab ICT juga di lengkapi oleh koneksi internet mengingat pelaksanaan pengabdian kepada masyarakat ini melibatkan Media Sosial Instagram yang membutuhkan akses internet. Dalam gambar 3 diatas, narasumber menjelaskan pemanfaatan media instagram sebagai media pemasaran online marketing, serta berbagai pengalaman yang telah dilakukan oleh narasumber dalam memasarkan produknya melalui media instagram.

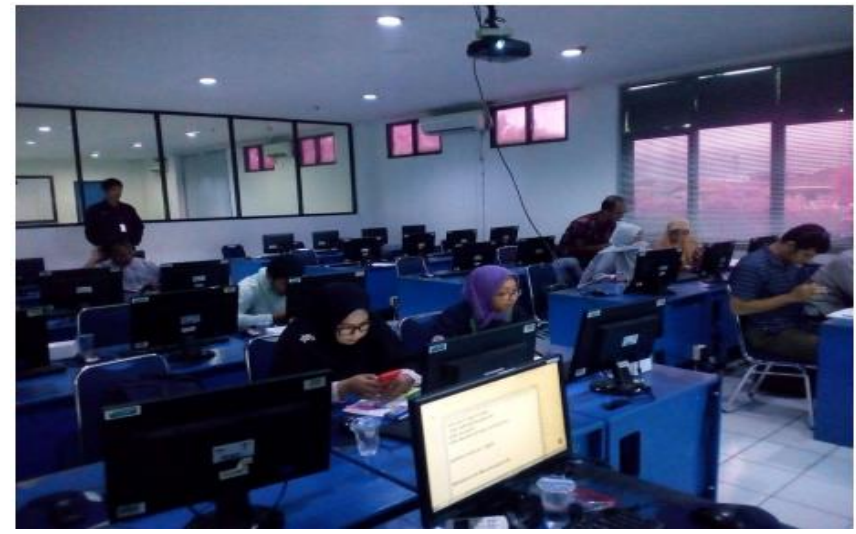

Gambar 2. Peserta pelatihan mempraktekkan materi yang diberikan dengan memasarkan produk masing-masing peserta. 
Pengabdian kepada masyarakat berupa pelatihan pemasaran produk melalui media online Instagram sebagai media online marketing untuk memasarkan produk UKM yang ada di kelurahan parung serab, tidak hanya berupa teori saja akan tetapi juga di implementasikan langsung melalui media instagram. Narasumber yang memberikan pemaparan tidak hanya menyampaikan pengunaan instagram dalam memasarkan produk akan tetapi juga berbagi pengalaman mengenai usaha yang dijalankannya. Setelah pemaparan materi selesai, para peserta mempraktekkan apa yang telah di sampaikan narasumber sebelumnya. Klau dilihat pada gambar 2 diatas, para peserta ada yang menggunakan komputer dan ada juga yang menggunakan smartphone untuk mengakses media sosial Instagram. Hal ini disebabkan karena ada sebagian peserta yang memang familier dengan menu instagram yang diakses melalui smartphone. Dan keberadaan smartphone juga selalu ada dimana mereka berada, jadi mengakses media sosial melalui smartphone lebih terbiasa bagi sebagian peserta.

Dengan adanya pelatihan pemasaran produk melalui media sosial instagram, peserta memahami bahwa dalam dunia bisnis peranan media sosial dapat dijadikan ajang promosi produk mereka. Para peserta juga dapat memahami bagaimana pemasaran produk melalui media sosial instagram. Selain bagaimana membuat konten produk yang menarik dan selalu diupdate guna menarik pelanggan. Penggunaan instagram ads juga dapat membantu produk UKM untuk mempromosikan produk mereka.

\section{Kesimpulan}

Dari hasil pelaksanaan pengabdian kepada masyakat berupa pelatihan bagaimana memasarkan produk melalui media instagram dapat ditarik bebarapa kesimpulan bahwa pelaksanaan pengabdian kepada masyarakat ini dapat dijalankan dengan baik. Para peserta juga merasa senang dalam mengikuti pelatihan, karena bagaimanapun sebuah produk akan dikenal dan diketahui calon pelanggan memerlukan tempat pemasaran produk. Dan dalam era serba digital ini, pemasaran produk melalui media sosial instagram sudah tepat mengingat sudah banyak orang menggunakan media sosial ini sebagai sarana marketing online dan penggunanya pun semakin bertambah sehingga kita tidak perlu repot-report mengumpulkan orang dalam satu wadah. Berdasarkan wawancara dengan peserta pelatihan materi yang diberikan dan disampaikan dalam seminar juga dinilai padat dan cukup jelas sehingga peserta dapat mengikut dengan baik.

\section{Daftar Pustaka}

Bidang Politik, D., \& Dan Sosial Budaya James Situmorang, P. R. (n.d.). Pemanfaatan Internet Sebagai New Media. In journal.unpar.ac.id. Retrieved May 8, 2021, from http://journal.unpar.ac.id/index.php/JurnalAdministrasiBisnis/article/viewFile/418/402

Indika, D. R., \& Jovita, C. (2017). Media Sosial Instagram Sebagai Sarana Promosi Untuk Meningkatkan Minat Beli Konsumen. Jurnal Bisnis Terapan, 1(01), 25-32. https://doi.org/10.24123/jbt.v1i01.296

Moch, H., Purwidiantoro, D., Fajar, K. S. W., \& Hadi, W. (2016). PENGARUH PENGGUNAAN MEDIA SOSIAL TERHADAP PENGEMBANGAN USAHA KECIL MENENGAH (UKM). Pengaruh Penggunaan Media Sosial Terhadap Pengembangan Usaha Kecil Menengah (UKM) Jurnal EKA CIDA, 1(1), 30. http://journal.amikomsolo.ac.id/index.php/ekacida/article/view/19

Pramdia Arhando Julianto. (n.d.). UMKM Harus Mampu Manfaatkan Media Sosial. https://ekonomi.kompas.com/read/2017/07/31/230406026/umkm-harus-mampumanfaatkan-media-sosial

Priambada, S. (2015). Manfaat penggunaan media sosial pada usaha kecil menengah (UKM). SESINDO 2015, 2015. 